\title{
IMPROVED SENSITIVITY AND REPRODUCIBILITY OF THE PCR METHOD FOR DETECTION OF Listeria spp. AND L. monocytogenes IN MILK
}

\author{
LAKICEVIC BRANKICA*, STJEPANOVIC ALEKSANDRA*, TOLINACKI MAJA**, GOLIC NATAŠA** \\ and TOPISIROVIC L**
}

\begin{abstract}
*Institute of Meat Hygiene and Technology, Belgrade, Serbia
**Institute of Molecular Genetics and Genetic Engineering, Belgrade, Serbia

(Received $4^{\text {th }}$ October 2010)

Listeria monocytogenes is a facultative intracellular Grampositive bacterium, ubiquitous in nature and capable of causing listeriosis in humans and animals. Conventional microbiological techniques and modern molecular approaches are currently used for the isolation and detection of $L$. monocytogenes in food samples. The aim of this study was to improve the sensitivity and reproducibility of PCR for the detection of Listeria spp. in milk. For that purpose milk samples were artificially inoculated with serial dilutions of $L$. monocytogenes 4b ATCC 19115 and L. innocua ATCC 33090. The results obtained on artificially contaminated milk samples indicated that incubation time and target genes have an influence on the sensitivity of PCR detection. The best results were obtained after $24 \mathrm{~h}$ of preenrichment, with primers complementary to the hlyA gene, when it was possible to detect $1 \mathrm{CFU} / \mathrm{mL}$ of Listeria spp.
\end{abstract}

Key words: detection, Listeria spp., L. monocytogenes, milk, PCR

\section{INTRODUCTION}

Listeria monocytogenes is a Gram-positive opportunistic pathogen that has been isolated from many natural and human-created environments (Farber and Peterkin, 1991). Pathogenic and nonpathogenic strains of Listeria are ubiquitous in nature and can be isolated from the soil, vegetables and natural waters, as well as from healthy animals and man (Roberts and Wiedmann, 2003). L. monocytogenes is the most pathogenic species of this genus, although infections mainly occur in neonates, pregnant women, the elderly and immunecompromised individuals (McLaughlin, 1997). The primary mode of transmission of $L$. monocytogenes to humans is the consumption of contaminated minimally processed food (Schlech, 2000; Kathariou, 2002; Shen et al., 2006). Several large outbreaks of listeriosis have been associated with contaminated commercial foodstuffs, such as vegetables, milk, and meat products, on which these bacteria can multiply even at low temperatures (Schuchat et al., 1991). Usually, the presence of any Listeria species in food is an indicator of poor hygiene 
(McLaughlin, 1997). Increased public awareness of the health-related and economic impacts of food contamination and food borne illnessess has resulted in greater efforts to develop sensitive methods for pathogen detection and identification. Conventional phenotypic assays are time-consuming, characterized by low sensitivity and may fail to detect strains of bacteria that are present in the samples at low concentrations or that have unusual phenotypic profiles (Tang et al., 1998). Advances in molecular technologies, particularly the PCR methodology, have allowed more reliable microbial identification and surveillance. PCR techniques are more sensitive, highly specific and allow more rapid processing times, and enhance the likelihood of detecting bacterial pathogens without the need for isolating pure cultures (Aznar and Alarcón 2003; Cocolin, et al., 2002).

In this paper, a direct identification of Listeria spp. in milk samples by a molecular method is described.

\section{MATERIALS AND METHODS}

Bacterial strains and growth conditions. The standard strains of Listeria monocytogenes 4b ATCC 19115 and Listeria innocua ATCC 33090 were obtained from The American Type Culture Collection (ATCC; Manassas, Va., USA), and used for artificial contamination of pasteurized milk samples. Standard strains were grown on brain-heart agar (BHA) (Merck, GmbH Darmatadt, Germany) and buffered peptone water (Merck) at $37^{\circ} \mathrm{C}$.

Samples. Artificially inoculated samples were prepared as follows: $40 \mathrm{~mL}$ of pasteurized milk were homogenized in $360 \mathrm{~mL}$ of half-concentrated Fraser broth, using a stomacher (MIX 2, AES Chemunex, France) for $1 \mathrm{~min}$. The resulting mixture was distributed in $40 \mathrm{~mL}$ aliquots inoculated with $400 \mu \mathrm{L}$ of 10 -fold serial dilutions of standard strains in sterile saline $(0.9 \% \mathrm{NaCl})$, covering the range from 1 to $1 \times 10^{7} \mathrm{CFU} \mathrm{mL} \mathrm{m}^{-1}$ (determined by plate count on $\mathrm{BHA}$ ). DNA was extracted from $10 \mathrm{~mL}$ of mixture, after $0 \mathrm{~h}, 2 \mathrm{~h}$ and $6 \mathrm{~h}$, and from $1 \mathrm{~mL}$ after $24 \mathrm{~h}$ of incubation at $37^{\circ} \mathrm{C}$.

DNA extraction. Two methods for DNA extraction from milk were evaluated, one using enzymatic treatment for bacterial lysis by using DNeasy Tissue Kit (Qiagen GmbH, Germany) according to the manufacturer's protocol for Grampositive bacteria and the other using zirconia beads for lysis (Randazzo et al., 2002).

PCR amplification conditions. PCR was performed in a final volume of $50 \mu \mathrm{L}$ containing 1xPCR buffer (10xPCR buffer: $500 \mathrm{mM} \mathrm{KCl}, 100 \mathrm{mM}$ Tris- $\mathrm{HCl}, 0.8 \%$ Nonidet P40), $2.5 \mathrm{mM} \mathrm{MgCl}_{2}, 200 \mu \mathrm{M}$ of each dNTP, $2.5 \mu \mathrm{M}$ of each primer, $1 \mathrm{U}$ of Taq polymerase (Fermentas UAB, Lithuania) and 0.1-1 $\mu \mathrm{g}$ of DNA template. The samples were amplified in a DNA thermal cycler (Flexigene, Techne, UK) with primers LM1 (5'-CCT AAG ACG CCA ATC GAA-3') and LM2 (5'-AAG CGC TTG CAA CTG CTC-3'), complementary to the hlyA gene and LI1 (5'-CTC CAT AAA GGT GAC CCT-3') and U1 (5'-CAG CMG CCG CGG TAA TWC-3') complementary to $16 \mathrm{~S}$ rDNA, 5 min at $94^{\circ} \mathrm{C}, 35$ cycles of $30 \mathrm{~s}$ at $94^{\circ} \mathrm{C}, 45 \mathrm{~s}$ at $50^{\circ} \mathrm{C}, 45 \mathrm{~s}$ at $72^{\circ} \mathrm{C}$ and the final extension of $5 \mathrm{~min}$ at $72^{\circ} \mathrm{C}$ (Aznar and Alarcón, 2003). List of primers 
used in this study is given in Table 1. All PCR products were analyzed by agarose gel electrophoresis on $1 \%$ and $2 \%$ (wt/vol) agarose gels in 1xTBE buffer (10xTBE: $89 \mathrm{mM}$ Tris, $89 \mathrm{mM}$ boric acid, 2 mM EDTA) (Fermentas), at a constant voltage $80 \mathrm{~V}$ for $1 \mathrm{~h}$ and visualized by CCD camera Bio Doc Analyze Darkhood (Biometra, Gottingen, Germany). All PCR products were run next to the DNA molecular standards "MassRuler"M DNA Ladder" (Fermentas) and "GeneRuler" ${ }^{\mathrm{TM}}$ DNA Ladder Mix" (Fermentas).

\section{RESULTS}

Assay design. The assay was designed to identify and distinguish Listeria spp. and $L$. monocytogenes from milk samples. Two sets of PCR primers were used to amplify two target genes ( $h / y A$ and $16 S$ rDNA), with expected 702 bp and 938 bp amplicons, respectively. Two methods for DNA extraction from milk were evaluated: one using enzymatic treatment for bacterial lysis and the other using zirconia beads for lysis. Results showed that two methods yielded similar amounts of bacterial DNA. The DNeasy Tissue Kit, being faster and easier to implement, was used for extracting DNA from artificially contaminated samples and from pre-enrichment cultures.

Validation with standard strains. The assay was initially validated with standard strains L. monocytogenes 4b ATCC 19115 and L. innocua ATCC 33090. The assay correctly identified both strains. Moreover, when DNA from non-Listeria strains, such as Campylobacter jejuni, Escherichia coli 0157:H7, Proteus mirabilis, Proteus vulgaris, Yersinia enterocolitica, Bacillus cereus, Bacillus subtilis, Enterococcus faecalis, Staphylococcus aureus and Lactobacillus plantarum, was used in the PCR, no PCR amplicon, of any size, was obtained (data not shown). Therefore, using primers directly on DNA extracted from microbial mixtures containing Listeria spp. facilitates specific detection of Listeria by PCR amplification.

Determination of the limit of detection. Different pre-enrichment incubation times ( $0 \mathrm{~h}, 2 \mathrm{~h}, 6 \mathrm{~h}$, and $24 \mathrm{~h}$ ) and target genes for PCR assay ( $h / y A$ and $16 \mathrm{~S} \mathrm{rDNA})$ were tested on artificially contaminated pasteurized milk samples, in order to optimize the experimental conditions for detection of Listeria spp., suitable for routine laboratory analysis. The limit of detection was first determined using serial dilutions of the cell cultures diluted 10-fold from 1:10 to $1: 10^{7}$ (the number of cells in the undiluted sample was $10^{8} \mathrm{CFU} \mathrm{mL}^{-1}$ ). The primers LI1/U1 and LM1/LM2 used in this study were proven highly specific for Listeria spp. and $L$. monocytogenes, respectively. The results obtained in the direct PCR reaction (0h) showed that sensitivity for the detection of $L$. monocytogenes, with primers

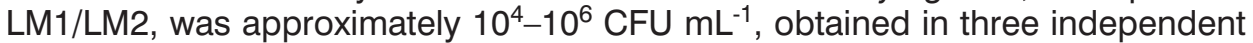
experiments (Fig. 1). In addition, the results showed that it was possible to detect L. innocua in all serial dilutions by using primers LI1/U1 (Fig. 1).

Further, direct PCR detection (0 h) of Listeria spp., without pre-enrichment, was compared with detection after $2 \mathrm{~h}, 6 \mathrm{~h}$ and $24 \mathrm{~h}$ of pre-enrichment. Results obtained with primers LM1/LM2 directed to the hlyA gene showed that the 
detection of $L$. monocytogenes increases over time. The best sensitivity result was achieved after $24 \mathrm{~h}$ incubation, detecting one CFU mL-1 (Fig 2).

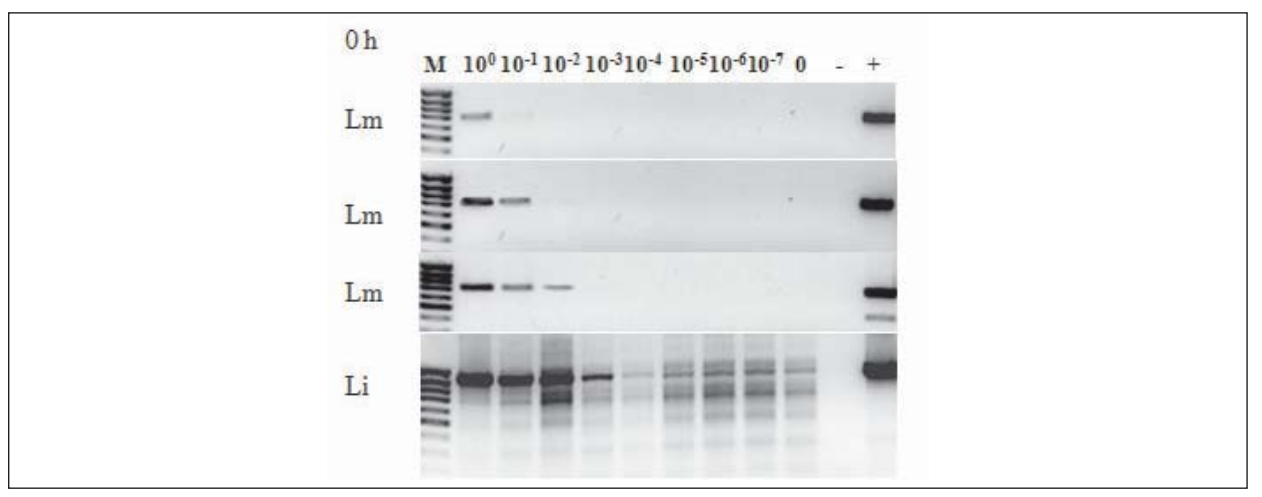

Figure 1. Agarose gel electrophoresis of the PCR products obtained by using primers LM1/LM2 and LI1/U1 on DNA isolated from artificially inoculated milk samples incubated for $0 \mathrm{~h}$ : M - MassRulerTM DNA Ladder, $10^{0}-10^{-7}$ - serial dilutions of $L$. monocytogenes 4b ATCC 19115 (Lm) and L. innocua ATCC 33090 (Li), 0 noninoculated sample, "“- - negative control, "+" - positive control

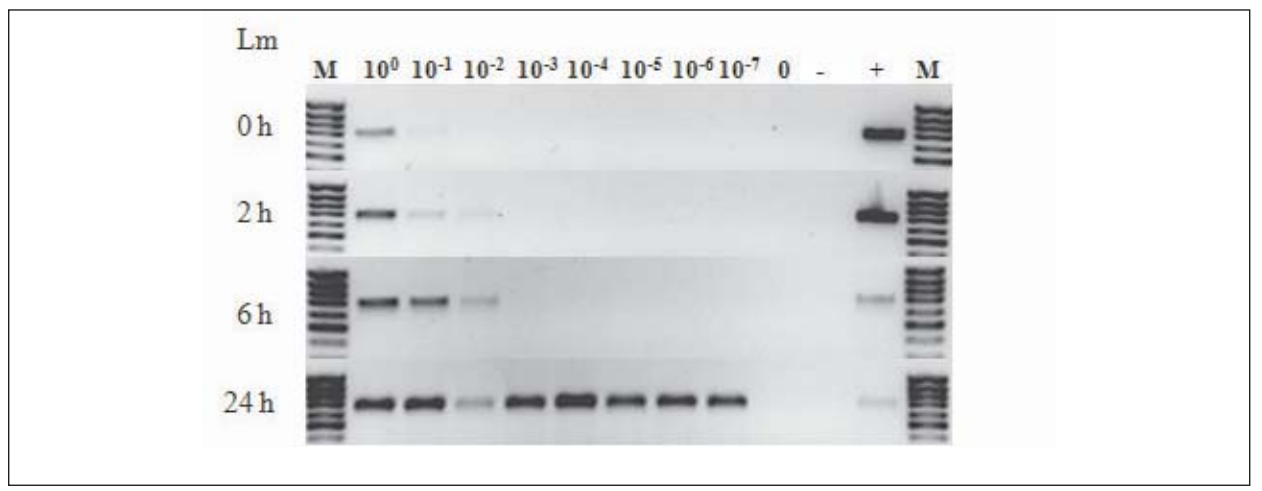

Figure 2. Agarose gel electrophoresis of the PCR products obtained by using primers LM1/LM2 on DNA isolated from artificially inoculated milk samples incubated for $0 \mathrm{~h}$, $2 \mathrm{~h}, 6 \mathrm{~h}$ and $24 \mathrm{~h}$ : M - MassRuler ${ }^{\mathrm{TM}}$ DNA Ladder, $10^{0}-10^{-7}$ - serial dilutions of $L$. monocytogenes 4b ATCC 19115 (Lm), 0 - noninoculated sample, "-" - negative control, "+" - positive control.

Interestingly, the results obtained after reamplification of the PCR products for $0 \mathrm{~h}$ of incubation, were similar to the result obtained in direct PCR reaction and did not have an influence on the sensitivity of the PCR detection (Fig 3). 


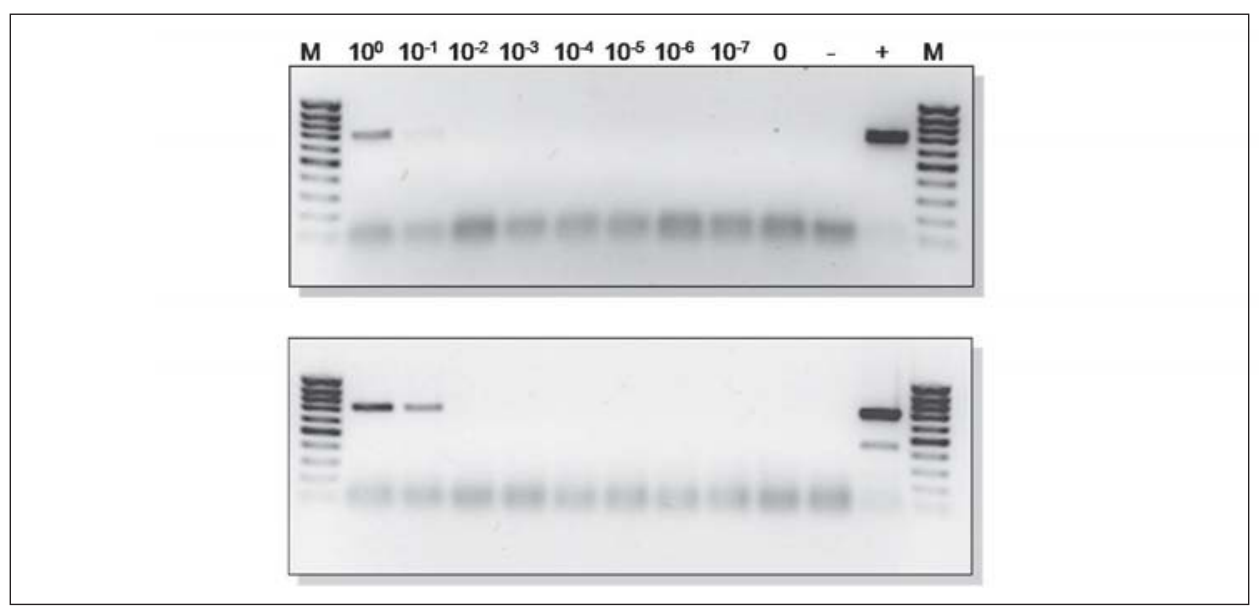

Figure 3. Agarose gel electrophoresis of the PCR products obtained after PCR amplification $(A)$ and reamplification $(B)$ reactions by using primers LM1/LM2 on DNA isolated from artificially inoculated milk samples incubated for $0 \mathrm{~h}$ : M - MassRuler TM DNA Ladder, $10^{0}-10^{-7}$ - serial dilutions of L. monocytogenes 4b ATCC 19115, 0 noninoculated sample, "-" - negative control, "+" - positive control

\section{DISCUSSION}

The detection and identification of Listeria spp. have attracted the attention of many researchers throughout the world (Aznar and Alarcón, 2003; Cocolin, et al., 2002; Curiale and Lewus, 1994; Kaur et al., 2007; Willis et al., 2006). This specific interest is related to the presence of $L$. monocytogenes, one of the most important food-borne pathogens. It is widely diffused in the environment and it can cause the contamination of food through the processing environment, from the raw material to the final product, and even persists after cleaning (Pan et al., 2006). The food industry needs a tool to trace sources of contamination and assess whether cleaning procedures are adequate. Recent developments in molecular diagnostics of $L$. monocytogenes include rapid and reliable methods for the detection of low concentrations of $L$. monocytogenes from a variety of food and environmental samples (Aznar and Alarcón, 2003; Cocolin et al., 2002; Kaur et al., 2007).

The aim of this study was to standardize a fast, reliable and highly sensitive method for the detection of $L$. monocytogenes and Listeria spp. in order to shorten the time for routine laboratory diagnostics of this pathogen in milk. The validation of the PCR method was performed on artificially inoculated milk samples with serial dilutions of $L$. monocytogenes 4b ATCC 19115 and L. innocua ATCC 33090 . The obtained results indicated that incubation time and target genes have an influence on the sensitivity of the PCR detection method that was in concordance with the limits of detection reported by Aznar and Alarcón 2003 (limit of detection, $1 \mathrm{CFU} / \mathrm{mL}$ ). The assay presented in this study shows very high 
specificity for the detection and identification, with pure isolates, as well as with DNA isolated directly from milk. Negative controls incorporated at all stages of the assay showed no false positive identification. However, when 16S rDNA genes were used as target for PCR reaction, while seeming to be more sensitive, false positives may arise from residual nucleic acid contaminants of other bacteria in milk.

Since the assay has been designed for detecting food-borne pathogens, the technique was validated with artificially contaminated milk. Two methods for DNA extraction were tested in order to remove potential PCR inhibitors from milk during DNA extraction. Both protocols for DNA extraction were successful in removing potential PCR inhibitors from milk, as well as incorrectly identifying bacteria.

Finally, the time to final identification and determination of antimicrobial susceptibility is generally 1 to 3 days (Tang et al, 1998). In contrast, the PCR assay, including DNA extraction, PCR amplification and data analysis, can be completed in less than $8 \mathrm{~h}$. This assay can also be adopted by small public health laboratories, food testing laboratories, and food industries, which cannot afford more expensive methods and equipment or trained technicians.

In conclusion, we have standardized high-throughput PCR assay for the detection of Listeria spp. and $L$. monocytogenes from milk samples. The assay has been successfully validated. The assay can provide "same-day" identification, which represents a significant reduction in time compared to conventional microbiological methods for identification of Listeria spp. from positive food samples. This assay represents a significant improvement over conventional techniques due to its rapid and non-tedious format.

ACKNOWLEDGMENTS:

This work was funded by the Ministry of Science of the Republic of Serbia, grant No.: 173019.

Address for correspondence:

Nataša Golić, PhD

Institute of Molecular Genetics and Genetic Engineering

University of Belgrade

Vojvode Stepe 444a, P.O.Box 23

11010 Belgrade, Serbia

E-mail: lab6@eunet.rs; nalebeli@eunet.rs

\section{REFERENCES}

1. Aznar R, Alarcón B, 2003, PCR detection of Listeria monocytogenes: a study of multiple factors affecting sensitivity, J Appl Microbiol, 95, 958-66.

2. Cocolin L, Rantsiou K, lacumin L, Cantoni C, Comi G, 2002, Direct identification in food samples of Listeria spp. and Listeria monocytogenes by molecular methods, Appl Environ Microbiol, 68, 6273-82.

3. Curiale MS, Lewus C, 1994, Detection of Listeria monocytogenes in samples containing Listeria innocua, J Food Prot, 57, 1048-51.

4. Farber JM, Peterkin PI, 1991, Listeria monocytogenes, a food-borne pathogen, Microbiol Rev 55, 476-511. 
5. Kaur S, Malik SVS, Vaidya VM, Barbuddhe SB, 2007, Listeria monocytogenes in spontaneous abortions in humans and its detection by multiplex PCR, J Appl Microbiol, 103, 1889-96.

6. McLaughlin J, 1997, Animal and human listeriosis: a shared problem?, Vet J, 153, 3-5.

7. Pan Y, Breidt Jr F, Kathariou S, 2006, Resistance of Listeria monocytogenes biofilms to sanitizing agents in a simulated food processing environment, Appl Environ Microbiol, 72, 7711-7.

8. Roberts AJ, Wiedmann M, 2003, Pathogen, host and environmental factors contributing to the pathogenesis of listeriosis, Cell Mol Life Sci, 60, 904-18.

9. Tang YW, Ellis NM, Hopkins MK, Smith DH, Dodge DE and Persing DH, 1998, Comparison of phenotypic techniques for identification of unusual aerobic pathogenic gram-negative bacilli, $J$ Clin Microbiol 36, 3674-9.

10. Schlech WF, 2000, Foodborne listeriosis, Clin Infect Dis, 31, 770-5.

11. Kathariou S, 2002, Listeria monocytogenes virulence and pathogenicity, a food safety perspective, $J$ Food Prot, 65, 1811-29.

12. Shen Y, Liu Y, Zhang Y, Cripe J, Conway W, Meng J, Hall G, Bhagwat AA, 2006, Isolation and characterization of Listeria monocytogenes isolates from ready-to-eat foods in Florida, Appl Environ Microbiol, 72, 5073-6.

13. Schuchat A, Swaminathan B, Broome CV, 1991, Epidemiology of human listeriosis, Clin Microbiol Rev, 4, 169-83.

14. Randazzo CL, Torriani S, Akkermans ADL, De Vos WM, Vaughan EE, 2002, Diversity, dynamics, and activity of bacterial communities during production of an artisanal sicilian cheese as evaluated by $16 \mathrm{~S}$ rRNA analysis, Appl Environ Microbiol 68, 1882-92.

15. Willis C, Baalham T, Greenwood M, Presland F, 2006, Evaluation of a new chromogenic agar for the detection of Listeria in food. J Appl Microbiol 101, 711-7.

\title{
POBOLJŠANA SENZITIVNOST I REPRODUCIBILNOST PCR METODE ZA DETEKCIJU Listeria spp. I L. monocytogenes U MLEKU
}

\author{
LAKIĆEVIĆ BRANKICA, STJEPANOVIĆ ALEKSANDRA, TOLINACKI MAJA, \\ GOLIĆ NATAŠA i TOPISIROVIĆ L
}

\section{SADRŽAJ}

Listeria monocytogenes, prouzrokovač listerioze kod ljudi i životinja, je fakultativan intraćelijski mikroorganizam široko rasprostranjen u prirodi. U cilju izolacije i detekcije L. monocytogenes iz hrane koriste se tradicionalne mikrobiološke i nove molekularno-genetičke metode. Cilj ovog rada je bio povećanje osetljivosti i ponovljivosti PCR metode u detekciji L. monocytogenes u mleku. $U$ tu svrhu, uzorci pasterizovanog mleka su kontaminirani serijskim razblaženjima sojeva L. monocytogenes 4b ATCC 119115 i Listeria innocua ATCC 33090. Dobijeni rezultati na veštački kontaminiranim uzorcima pasterizovanog mleka, ukazuju da osetljivost PCR metode zavisi od perioda inkubacije i izbora prajmera. Najbolji rezultati su dobijeni nakon $24 \mathrm{~h}$ inkubacije, pomoću prajmera za hlyA gen, kada je bilo moguće detektovati 1 ćeliju L. monocytogenes tj. $1 \mathrm{CFU} / \mathrm{ml}$. 